\title{
Protection of Man from Natural Infection with Influenza A2 Hong Kong Virus by Amantadine: A Controlled Field Trial
}

\author{
N. OKER-BLOM,* M.D. ; T. HOVI, $†$ M.D. ; P. LEINIKKI, $\dagger$ M.D. ; T. PALOSUO, $†$ M.D. \\ R. PETTERSSON, $\ddagger$ M.B. ; J. SUNI, $\ddagger$ M.B.
}

British Medical fournal, 1970, 3, 676-678

\begin{abstract}
Summary: Prophylactic administration of amantadine $S$ in doses of $100 \mathrm{mg}$. twice a day offered statistically significant protection against influenza $\mathrm{A2}$ infection in a double-blind field trial involving 391 medical student volunteers during the influenza A2 Hong Kong epidemic in Helsinki in the winter of 1969. Serologically verified influenza, as measured by complement fixation and/or haemagglutination inhibition, occurred in 27 out of 192 students in the amantadine group against 57 out of 199 in the placebo group, giving a protection rate of $52 \%$.
\end{abstract}

\section{Introduction}

Amantadine (1-adamantanamine hydrochloride) is known to inhibit the growth of some strains of influenza and other viruses in tissue culture (Davies et al., 1964; Maassab and Cochran, 1964; Cochran et al., 1965; Hoffmann et al., 1965; Neumayer et al., 1965; Plotkin, 1965; Schild and Sutton, 1965; Oker-Blom and Andersen, 1966; Wallbank et al., 1966). It also inhibits virus growth in laboratory animals to some extent (Davies et al.. 1964, 1965; Cochran et al., 1965; Grunert et al., 1965; Schild and Sutton, 1965; Bryans et al., 1966; Wendel et al., 1966).

In 1963 it was reported that experimental infection in man with an attenuated influenza A2 virus strain was inhibited by amantadine as measured by seroconversion and frequency and severity of clinical illness (Jackson et al., 1963). Similar results in experimental and naturally occurring influenza A2 infection in man have since been reported by several authors (Halonen et al., 1965; Stanley et al., 1965; Lee et al., 1966; Quilligan et al., 1966; Wendel et al., 1966; Finklea et al., 1967). Some workers, however, could not detect any effect of amantadine on seroconversion in experimental infection with wild strains of influenza A2 virus, though occurrence and severity of illness were appreciably diminished (Stanley et al., 1965). Furthermore, a strain known to be highly sensitive to the drug in tissue culture (Schild and Sutton, 1965) was reported to be resistant in experimental infection in man (Tyrrell et al., 1965). Some of the early trials showing a protective effect, many of which were carried out in closed institutions, have also been criticized as inconclusive (Sabin, 1967). Of the more recent trials one carried out during the epidemic in 1967-8 indicated a clear protective effect of amantadine against the spreading of influenza virus among members of the families of index cases (Galbraith et al., 1969a). In a similar trial carried out during the Hong Kong influenza epidemic, however, no protective effect was obtained (Galbraith et al., 1969b).

Thus the effects of amantadine are by no means clear, and because of the great importance of influenza prophylaxis further controlled field trials during an epidemic of influenza A2 virus are required. Our present paper describes a doubleblind field trial carried out among medical students during an outbreak of epidemic influenza in Helsinki in the winter of 1969 in order to ascertain whether amantadine would protect against natural influenza virus infection in an open community.

\footnotetext{
- Director.

Member of Scientific Staff.

\# Research Assistant

Department of Virology, University of Helsinki, Helsinki 29, and the Research Laboratories Medica Ltd, Helsinki 51, Finland.
}

\section{Subjects and Methods}

Timing of Trial.-The first virologically verified cases of influenza A2 Hong Kong virus infections that were not acquired abroad occurred in Helsinki in late December 1968 and early January 1969. The trial was begun on 20 January 1969 and was continued for 30 days without interruption.

Participants.-A total of 391 medical students of the University of Helsinki participated voluntarily in the study; 132 were female and 259 male. Their average age was 22 years. To avoid the possible effect of different "infection pressures" among students at different levels of their studies, the participants were first grouped according to the year of their studies. Each subgroup was then randomly divided into amantadine and placebo groups.

Medication.-During the trial participants took one tablet of either drug or placebo twice a day. Each amantadine (Fluviral) tablet contained $100 \mathrm{mg}$. of 1-adamantanamine hydrochloride. The placebo consisted of similar tablets containing calcium lactate. The tablets were supplied by the Research Laboratories Medica Ltd., Helsinki. At the end of the trial 192 students had received amantadine and 199 had had placebo. All participants who returned questionnaires claimed to have taken tablets regularly.

Clinical Data.-Those who became ill during the trial were not examined clinically. Information about symptoms was obtained only by questionnaires delivered to the participants before the trial. They were asked to report any kind of possible symptoms of influenza from 10 January to 31 March 1969. Data on possible adverse symptoms of drug treatment were also asked for. Questionnaires were returned by $73 \%$ of the amantadine group and $76 \%$ of the placebo group. Of those with serologically verified influenza the percentage returns were 82 and 84.

Virological Investigation.-Diagnosis of infection with influenza A2 Hong Kong virus was based on fourfold or greater increase in serum antibody levels as measured by complement fixation or haemagglutination inhibition methods. The first serum samples were collected between 15 and 20 January and the second between 5 and 10 March 1969. All sera were stored at $-20^{\circ} \mathrm{C}$. For haemagglutination inhibition tests sera were treated by the conventional method (Davenport and Minuse, 1964) to remove non-specific inhibitors. The haemagglutination antigen was prepared from allantoic fluids of eggs infected with influenza A2 Hong Kong virus, strain England $344 / 68$. The haemagglutination inhibition tests were carried out by standard micromethods, 4 units of antigen and $0.5 \%$ guinea-pig red blood cells being used. For complement fixation tests the standard micromethod of Lennette (1964) was used with minor modifications. Partially purified strainspecific V-antigen preparation from influenza A2 Hong Kong virus, a strain isolated in Finland in January 1969 (A2 Finland 7/69), was used as complement fixation antigen. Both haemagglutination and complement fixation antigens were prepared in the Orion Laboratories, Helsinki 51, and kindly supplied by Dr. A. Vaheri. Serological tests to measure antibodies against any other viruses were not performed. Attempts to isolate virus were made from a few cases only, the intention being to verify also by these means the type of virus causing the epidemic. Samples were taken by pharyngeal swabbing and inoculated into embryonated eggs and primary rhesus monkey kidney cell cultures. 


\section{Results}

The trial was carried out during the most active phase of the epidemic (see Chart). Influenza A2 Hong Kong virus was isolated from two out of four participating students with clinical influenza symptoms.

Pre-epidemic Level of Immunity.-The correlation between pre-epidemic haemagglutination inhibition and complement fixation titres was rather good. The geometric mean of the haemagglutination inhibition titres in the amantadine group was 22 and in the placebo group 23 . The mean complement fixation titres were 16 and 15 respectively. The amantadine group and the placebo group were thus well matched as regards the pre-epidemic level of immunity.

Reduction of Incidence of Serologically Verified Influenza Virus Infection by Amantadine.-There was fourfold or greater increase in haemagglutination inhibition antibodies in $18 / 192$ of the amantadine group and 55/199 of the placebo group (Table I). Sera from only 373 students were studied by the complement fixation test because of anticomplementarity or insufficient serum. Fourfold or greater increase in complement fixation antibodies occurred in $24 / 188$ of the students in the amantadine group and in $45 / 185$ in the placebo group (Table II). On the basis of the haemagglutination inhibition test, protection by amantadine was obtained irrespective of the level of pre-epidemic immunity (Table I). In contrast to the results of the haemagglutination inhibition test the difference between amantadine and placebo groups among students with low-titre complement fixation antibodies $(\leqslant 8)$ was not significant. Among students with moderate or high complement fixation titres $(\geqslant 16)$, on the other hand, protection obtained by amantadine was highly significant (Table II). The number of students in whom a fourfold or greater increase in the complement fixation and/or haemagglutination inhibition test was found was $27(14.1 \%)$ in the amantadine group and $59(29.6 \%)$ in the placebo group (Table III), giving a protection rate of $52 \%$.

Incidence of Clinical Illness in the Study Group.-In the placebo group 88 out of 152 students $(58 \%)$ who returned the questionnaire suffered from respiratory symptoms such as cough, rhinitis, and/or fever (Table IV). In the amantadine group the corresponding number was 62 out of $141(44 \%)$. Respiratory symptoms were reported by 16 out of 23 students with serologically verified influenza in the amantadine group and by 41 out of 50 in the placebo group, thus giving a protection rate of $68 \%$. Severity of clinical symptoms is difficult to evaluate on the basis of returned questionnaires only. According to the sparse data available the clinical course seemed, however, to be milder and of shorter duration in the amantadine group than in the placebo group. Frequency of

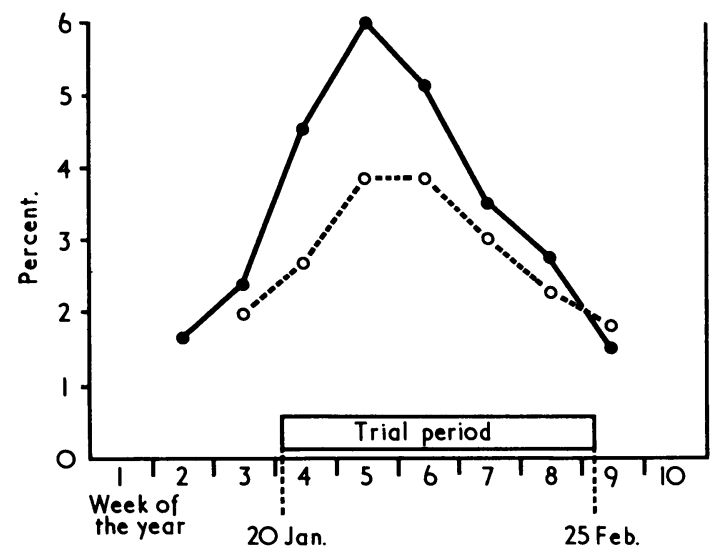

Epidemic of influenza A2 Hong Kong in Helsinki in 1969. Percentage of municipal workers absent from their job, $0-0$ (K. Penttinen, personal communication, 1970) or hospital personnel visiting the outpatient department, $0-\ldots$ (P. Leinikki, personal communication, 1970) before and during the trial non-influenzal respiratory illnesses, the aetiology of which was not studied, was similar in both groups-33 and $31 \%$ respectively.

Side-effects of Medication.-The participants in this study did not make any complaints about gastrointestinal symptoms during medication. Among neurological side-effects headache was most common- $8.7 \%$ in the amantadine group and $3.4 \%$ in the placebo group. One person in each group complained about difficulties in concentration. In addition, in the amantadine group five persons reported insomnia, three vertigo, one claimed to feel drunk, one had unspecific unpleasant feelings, and one was unwilling to do anything. The side-effects were, however, transient and mild. In addition two persons, not included in the final study group, stopped taking amantadine after a couple of days because of general unpleasant feelings.

\section{Discussion}

The need for controlled field trials to assess the protective value of amantadine during an outbreak of influenza A2 has been evident for some time. The trial presented in this paper took place during the first wave of the influenza A2 Hong Kong epidemic in Helsinki in the winter of 1969. The medical students lived in different parts of the city, either in their homes or as boarders. They thus represent a cross-section of students, and probably also of young adults of the city of Helsinki. The incidence of serologically proved influenza A2 infection in the placebo group was $29 \%$. Thus, considering

TABLE I.-Incidence of A2 Influenza Infection in Amantadine and Placebo Groups as Estimated by Fourfold or Greater Increase in Haemagglutination Inhibition Test

\begin{tabular}{|c|c|c|c|c|c|c|c|}
\hline \multirow{2}{*}{$\begin{array}{l}\text { "Pre- } \\
\text { epidemic" } \\
\text { Antibody } \\
\text { Status. } \\
\text { H.I. Titre }\end{array}$} & \multicolumn{3}{|c|}{ Amantadine } & \multicolumn{3}{|c|}{ Placebo } & \multirow{2}{*}{$\begin{array}{l}\text { Difference } \\
\text { Between } \\
\text { A and P }\end{array}$} \\
\hline & $\begin{array}{l}\text { No. } \\
\text { in } \\
\text { Group }\end{array}$ & $\begin{array}{c}\text { Fourfold } \\
\text { or Greater } \\
\text { Increase }\end{array}$ & $\%$ & $\begin{array}{l}\text { No. } \\
\text { in } \\
\text { Group }\end{array}$ & $\begin{array}{c}\text { Fourfold } \\
\text { of Greater } \\
\text { Increase }\end{array}$ & $\%$ & \\
\hline $\begin{array}{ll}\leqslant 10 & \ldots \\
\geqslant 20 & . . \\
\text { All titres } & \ldots\end{array}$ & $\begin{array}{r}98 \\
94 \\
192\end{array}$ & $\begin{array}{r}9 \\
9 \\
18\end{array}$ & $\begin{array}{l}9 \cdot 2 \\
9 \cdot 6 \\
9 \cdot 4\end{array}$ & $\begin{array}{r}106 \\
93 \\
199\end{array}$ & $\begin{array}{l}34 \\
21 \\
55\end{array}$ & \begin{tabular}{|l|}
$32 \cdot 1$ \\
$22 \cdot 6$ \\
$27 \cdot 6$
\end{tabular} & $\begin{array}{l}P=0.02 \\
0.1>P>0.05 \\
P<0.01\end{array}$ \\
\hline
\end{tabular}

TABLE II.-Incidence of A2 Influenza Infection in Amantadine and Placebo Groups as Estimated by Fourfold or Greater Increase in Complement Fixation Test

\begin{tabular}{|c|c|c|c|c|c|c|c|}
\hline \multirow{2}{*}{$\begin{array}{l}\text { "Pre- } \\
\text { epidemic" } \\
\text { Antibody } \\
\text { Status. } \\
\text { C.F. Titre }\end{array}$} & \multicolumn{3}{|c|}{ Amantadine } & \multicolumn{3}{|c|}{ Placebo } & \multirow{2}{*}{$\begin{array}{l}\text { Difference } \\
\text { Between } \\
\mathbf{A} \text { and } \mathbf{P}\end{array}$} \\
\hline & $\begin{array}{c}\text { No. } \\
\text { in } \\
\text { Group }\end{array}$ & $\begin{array}{l}\text { Fourfold } \\
\text { or Greater } \\
\text { Increase }\end{array}$ & $\%$ & $\begin{array}{c}\text { No. } \\
\text { in } \\
\text { Group }\end{array}$ & $\begin{array}{c}\text { Fourfold } \\
\text { or Greater } \\
\text { Increase }\end{array}$ & $\%$ & \\
\hline $\begin{array}{l}\leqslant 8 \\
\geqslant 16\end{array}$ & $\begin{array}{r}86 \\
102\end{array}$ & $\begin{array}{r}23 \\
1\end{array}$ & $\begin{array}{r}26 \cdot 7 \\
1.0\end{array}$ & $\begin{array}{l}87 \\
98\end{array}$ & $\begin{array}{l}28 \\
17\end{array}$ & \begin{tabular}{|l|}
$32 \cdot 2$ \\
$17 \cdot 3$
\end{tabular} & $\begin{array}{l}P>0.5 \\
P<0.01\end{array}$ \\
\hline All titres .. & 188 & 24 & $12 \cdot 8$ & 185 & 45 & $24 \cdot 3$ & $0.5>P>0.1$ \\
\hline
\end{tabular}

TABLE III.-Incidence of A2 Influenza Infection in Amantadine and Placebo Groups as Estimated by Fourfold or Greater Increase in Haemagglutination Inhibition (H.I.) andlor Complement Fixation (C.F.) Test

\begin{tabular}{|c|c|c|c|c|c|c|c|c|c|c|}
\hline & & \multirow{3}{*}{$\begin{array}{c}\text { No. } \\
\text { in } \\
\text { Group }\end{array}$} & \multicolumn{8}{|c|}{ Fourfold or Greater Antibody Increase } \\
\hline & & & \multicolumn{2}{|c|}{$\begin{array}{l}\text { C.F. and } \\
\text { H.I. }\end{array}$} & \multicolumn{2}{|c|}{ H.I. Only } & \multicolumn{2}{|c|}{$\begin{array}{l}\text { C.F. } \\
\text { Only }\end{array}$} & \multicolumn{2}{|c|}{$\begin{array}{l}\text { C.F. and/ } \\
\text { or H.I. }\end{array}$} \\
\hline & & & No. & $\%$ & No. & $\%$ & No. & $\%$ & No. & $\%$ \\
\hline $\begin{array}{l}\text { Amantadine } \\
\text { Placebo }\end{array}$ & 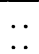 & $\begin{array}{l}192 \\
199\end{array}$ & $\begin{array}{l}15 \\
42\end{array}$ & $\begin{array}{r}7 \cdot 8 \\
21 \cdot 1\end{array}$ & $\begin{array}{r}3 \\
13\end{array}$ & $\begin{array}{l}1.6 \\
6.5\end{array}$ & $\begin{array}{l}9 \\
4\end{array}$ & $\begin{array}{l}4 \cdot 7 \\
2 \cdot 0\end{array}$ & $\begin{array}{l}27 \\
59\end{array}$ & $\begin{array}{l}14 \cdot 1 \\
29 \cdot 6\end{array}$ \\
\hline
\end{tabular}

TABLE IV -Incidence of Reported Respiratory Illness and Serologically Verified Influenza in Students in Amantadine and Placebo Groups

\begin{tabular}{|c|c|c|c|c|c|c|c|c|c|}
\hline \multirow{3}{*}{\multicolumn{2}{|c|}{ Groups }} & & \multirow{3}{*}{$\begin{array}{c}\text { Questionnaires } \\
\text { Returned }\end{array}$} & \multicolumn{6}{|c|}{ Respiratory Illness } \\
\hline & & & & \multicolumn{2}{|c|}{ Total } & \multicolumn{2}{|c|}{$\begin{array}{l}\text { Serologic } \\
\text { Influenza }\end{array}$} & \multicolumn{2}{|c|}{$\begin{array}{c}\text { Other } \\
\text { Infections }\end{array}$} \\
\hline & & & & No. & $\%$ & No. & $\%$ & No. & $\%$ \\
\hline $\begin{array}{l}\text { Amantadine } \\
\text { Placebo }\end{array}$ & & . & $\begin{array}{l}141 \\
152\end{array}$ & $\begin{array}{l}62 \\
88\end{array}$ & $\begin{array}{l}44 \\
58\end{array}$ & $\begin{array}{l}16 \\
41\end{array}$ & $\begin{array}{l}11 \\
26\end{array}$ & $\begin{array}{l}46 \\
47\end{array}$ & $\begin{array}{l}33 \\
31\end{array}$ \\
\hline
\end{tabular}


the timing, participants, and infection rate, the trial should give a reliable picture of the protective effect and possible side-effects of prolonged amantadine medication in young adults in an open community during an extensive outbreak of influenza A2.

The pre-epidemic level of immunity, as estimated by haemagglutination inhibition and/or complement fixation test, in the students in the placebo and amantadine groups showed that the groups were fully comparable. Irrespective of the methods used the incidence of serologically verified influenza infection was, however, significantly lower among students in the amantadine group.

When students in both groups were divided into subgroups according to pre-epidemic levels of immunity it was evident that pre-existing complement fixation antibodies offered a slight protection against serological influenza. Among students with pre-epidemic complement fixation titres $(\geqslant 16)$ amantadine protection was highly significant, the infection rate being $1 \%$ against $17 \%$ in the placebo group. In the haemagglutination inhibition test, on the other hand, no such difference could be shown. Study of the pre-epidemic level of immunity shows a good correlation between complement fixation and haemagglutination inhibition tests. The discrepancy seen between the two tests in estimating influenza $A 2$ infection could therefore probably be explained if one assumes that continuous amantadine medication diminishes the intection in vivo and especially the production of haemagglutinin and consequently the stimulation of haemagglutination inhibition antibodies. Such a hypothesis is to some extent supported by the slightly lower titres in cases where a fourfold or greater increase in the haemagglutination inhibition test was seen. If this is true the results of the complement fixation test should be more reliable and show that high protection by amantadine is obtained only in subjects with some basic immunity. This is in accordance with results obtained earlier by several authors (Jackson et al., 1963; Quilligan et al., 1966; Wendel et al., 1966; Galbraith et al., 1969a, 1969b). The possible failure of the haemagglutination inhibition test to reveal all cases of influenza infection and the significant protection obtained in students with initial complement fixation antibodies may explain the discrepancies between different trials.

Though the clinical data obtained from questionnaires are not quite reliable they are, however, in accordance with earlier findings, suggesting that prophylactic administration of amantadine may also, to some extent, suppress the symptoms of influenza A2 infection.

The available data concerning side-effects are too limited to warrant conclusions, but they support earlier ideas about the possible occurrence of neurological symptoms. Among the young adults participating in this trial such symptoms were, however, mild and transient.

To conclude, prophylactic treatment with amantadine offered significant protection against influenza $A 2$ infection in young adults in an open community during an epidemic.

We wish to express our thanks to the medical students who voluntarily participated in the trial, to Dr. S. Rosengard for his help in planning the trial, to Dr. A. Vaheri for supplying antigens, and to Mrs. Anja Kallionpää, Miss Raija Lahdensivu, Mrs. Pirkko Leino, and Miss Marja-Leena Vitikainen for technical help.

REFERENCES

Bryans, J. T., Zent, W. W., Grunert, R. R., and Boughton, D. C. (1966) Nature, 212, 1542.

Cochran, K. W., Maassab, H. F., Tsunoda, A., and Berlin, B. S. (1965) Annals of the Nerv York Academy of Sciences, 130, 432.

Davenport, F. M., and Minuse, E. (1964). In Diagnostic Procedures for Viral and Rickettsial Diseases, ed. E. H. Lennette and N. J. Schmidt, 3rd ed., p. 465. New York, American Public Health Association.

Davies, W. L., et al. (1964). Science, 144, 862.

Davies, W. L., Grunert, R. R., and Hoffmann, C. E. (1965). fournal of Immunology, 95, 1090 .

Immunology, 95, 1090.
Finklea, J. F., Hennessy, A. V., and Davenport, F. M. (1967). American

Gaurnal of Epidemiology, 85, 403 . Lancet, 2, 1026.

Galbraith, A. W., Oxford, J. S., Schild, G. C., and Watson, G. I. (1969b). Bulletin of the World Health Organization, 41, 677.

Grunert, R. R., McGahern, J. W., and Davies, W. L. (1965). Virology, $26,262$.

Halonen, P., Mujunen, R., and Mäntyiärvi, R. (1965). Sotilaslääketieteellinen Aikakausilehti, 40, 130 .

Hoffmann, C. E., Neumayer, E. M., Haff, R. F., and Goldsby, R. A. (1965). fournal of Bacteriology, 90, 623 . Jackson, G. G., Muldoon, R. L., and Akers, L. W. (1963). Antimicrobial
Agents and Chemotherapy, p. 703 .

Lee, S. H. S., Dobson, P. R., and van Rooyen, C. E. (1966). Chemotherapia,

Lennette, E. H. (1964). In Diagnostic Procedures for Viral and Rickettsial Diseascs, ed. E. H. Lennette and N. J. Schmidt, 3rd ed., p. 57. New York, American Public Health Association.

Maassab, H. F., and Cochran, K. W. (1964). Science, 145, 1443.

Neumayer, E. M., Haff, R. F., and Hoffmann, C. E. (1965). Proceedings of the Society for Experimental Biology and Medicine, 119, 393.

Oker-Blom, N., and Andersen, L. (1966). European fournal of Cancer, 2, 9.

Plotkin, S. A. (1965). Archiv für die gesamte Virusforschung, 16, 438.

Quilligan, J. J., jun., Hirayama, M., and Baerstein, H. D., jun. (1966). Schweizerische medizinische Wochenschrift, 96, 1689.

Sabin, A. B. (1967). Fournal of the American Medical Association, 200, 943.

Schild, G. C., and Sutton, R. N. P. (1965). British Fournal of Experimental Pathology, 46, 263.

Stanley, E. D., Muldoon, R. E., Akers, L. W., and Jackson, G. G. (1965). Annals of the New York Academy of Sciences, 130, 44

Tyrrell, D. A. J., Bynoe, M. L., and Hoorn, B. (1965). British fournal of Experimental Pathology, 46, 370.

Wallbank, A. M., Matter, R. E., and Klinikowski, N. G. (1966). Science,

152, 1760 .
Wendel, H. A., Snyder, M. T., and Pell, S. (1966). Clinical Pharmacology and Therapeutics, 7, 38. 